\title{
BUSINESS
}

\section{Carbon tax lite}

\section{The impact of a British tax on greenhouse-gas emissions has faded over time, as Geoff Brumfiel reports.}

E ight years ago Gordon Brown, then Britain's chancellor of the exchequer, - announced a wide-ranging 'climate levy' on industrial carbon emissions. He pledged that the levy would benefit the environment and encourage investment in cleaner technologies.

But a recent audit - one of the most farreaching of its type in the world - suggests that the scheme's bark was worse than its bite. The widely respected National Audit Office (NAO) reported in August that nearly 90\% of its estimated impact occurred even before the levy started in 2001, as firms reacted to the idea. Subsequent reductions that could be attributed to the actual tax itself were small.

"It appears that the announcement had more of an impact than the taxes," says Tim Yeo, a Conservative MP and chair of the House of Commons Environmental Audit Committee, which has an investigation of its own under way. The NAO estimated that the levy cut Britain's total annual industrial emissions of about 60 million tonnes of carbon by 3.1 million tonnes between 1999 and 2001, but by only 400,000 tonnes in subsequent years.

"I don't think the levy is doing very much," says Terry Barker, an economist at the University of Cambridge and chairman of the consultancy firm Cambridge Econometrics, which has carried out several analyses of the tax's impact for the Department of Food, Agriculture and Rural Affairs (DEFRA), which is responsible for its implementation.

\section{Soft targets}

As originally conceived, the climate levy would simply have taxed industrial users on their overall energy consumption. But the UK treasury, sensitive to charges from the Confederation of British Industry (CBI) and other lobby groups that such a tax would damage the competitiveness of UK firms, agreed to a more complex implementation that seems to have reduced its effectiveness.

Energy-intensive sectors such as brewing and bulk chemicals can win an $80 \%$ rebate on the tax if the sector as a whole is managing to meet emissions targets that they negotiate with DEFRA. For example, a 2001 agreement guaranteed brewers the rebate if they managed to cut energy use on every pint of beer produced by $9 \%$ over seven years - which they then did.

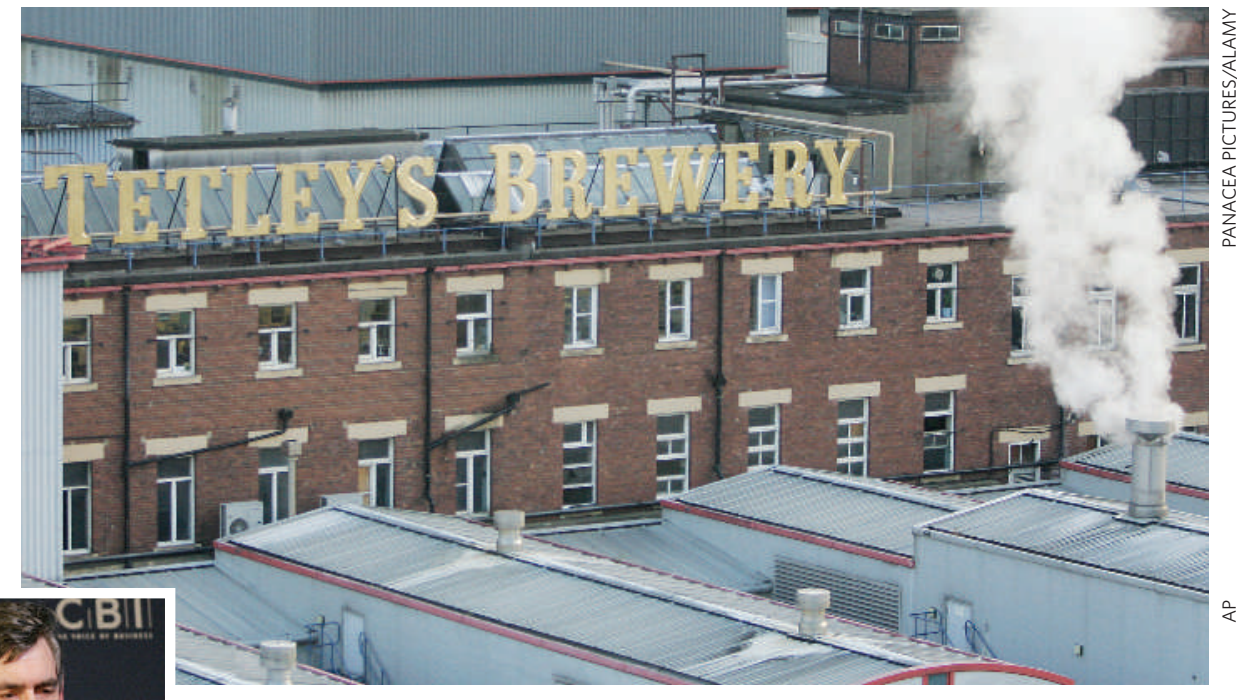

Gordon Brown's climate levy has had a modest impact on industry's carbon emissions.

According to Barker, DEFRA officials negotiating these targets lacked detailed knowledge of the sectors in question and were usually out-foxed by industry, agreeing to targets that the sectors could meet without much effort.

Matthew Farrow, head of environmental policy at the CBI, disagrees with this assessment, saying that both sides lacked information on how easily emissions cuts could be achieved. "When the agreements were first negotiated in many sectors, there wasn't much data," he says.

The NAO reports that the resulting agreements were usually modest in scope. They typically required sectors to cut their emissions per unit of production - not of total emissions. This meant that industries could increase overall emissions if production increased, and not lose their rebate. And when sector targets were renegotiated in 2004, ten sectors out of 45 renegotiated agreements with DEFRA that exempted them from $80 \%$ of the levy as long as they met a 2010 target that turned out to be actually above their reported 2004 emissions, when those figures became available.

As a result, the agreements part of the levy has fallen short of its goals, according to the NAO. It was supposed to deliver a 2.9-milliontonne annual reduction in carbon emissions by 2010 , but a revised estimate now puts this figure at 1.9 million tonnes. By contrast, it is estimated that rising energy prices and other factors will deliver a total of 2.4 million tonnes of annual reductions by 2010 .

According to the NAO, the impact of the levy on sectors excluded from agreements, such as retail and banking, is hard to gauge as they are not required to report their emissions.

Environmentalists say that even the full levy of 0.44 pence on a kilowatt-hour of electricity - less than $10 \%$ of the cost of the energy — is too small to make a difference. "The fact is that it didn't significantly hit the bottom line," says Mike Childs, head of campaigns at environmental group Friends of the Earth in London.

Nevertheless, many believe the levy has had a positive impact. It forced many sectors to look at their consumption, says Paul Ekins, head of the environmental
group at the Policy Studies Institute, a Londonbased think-tank. "Boards will have demanded reports on energy use, probably for the first time in their lives," he says. And despite being critical of the tax, Childs and others still see the levy as a useful starting point for Britain — and an example for other countries.

The UK government has announced that it will extend both the levy and the sector agreements until 2017. But Yeo says that his committee, when it reports next month, may advocate the renegotiation of these agreements to give the climate levy some much-needed teeth. 